Economics Development Analysis Journal

\title{
Strategies for The Development of Earthenware Craft Business
}

\author{
${ }^{1}$ Khafid Ismail ${ }^{\bowtie},{ }^{2}$ Sucihatiningsih DWP, ${ }^{3}$ Widiyanto \\ ${ }^{1}$ Economics Education Department, STKIP Nurul Huda Sukaraja \\ ${ }^{2}$ Economics of Development Department, Universitas Negeri Semarang \\ ${ }^{3}$ Economics Education Department, Universitas Negeri Semarang
}

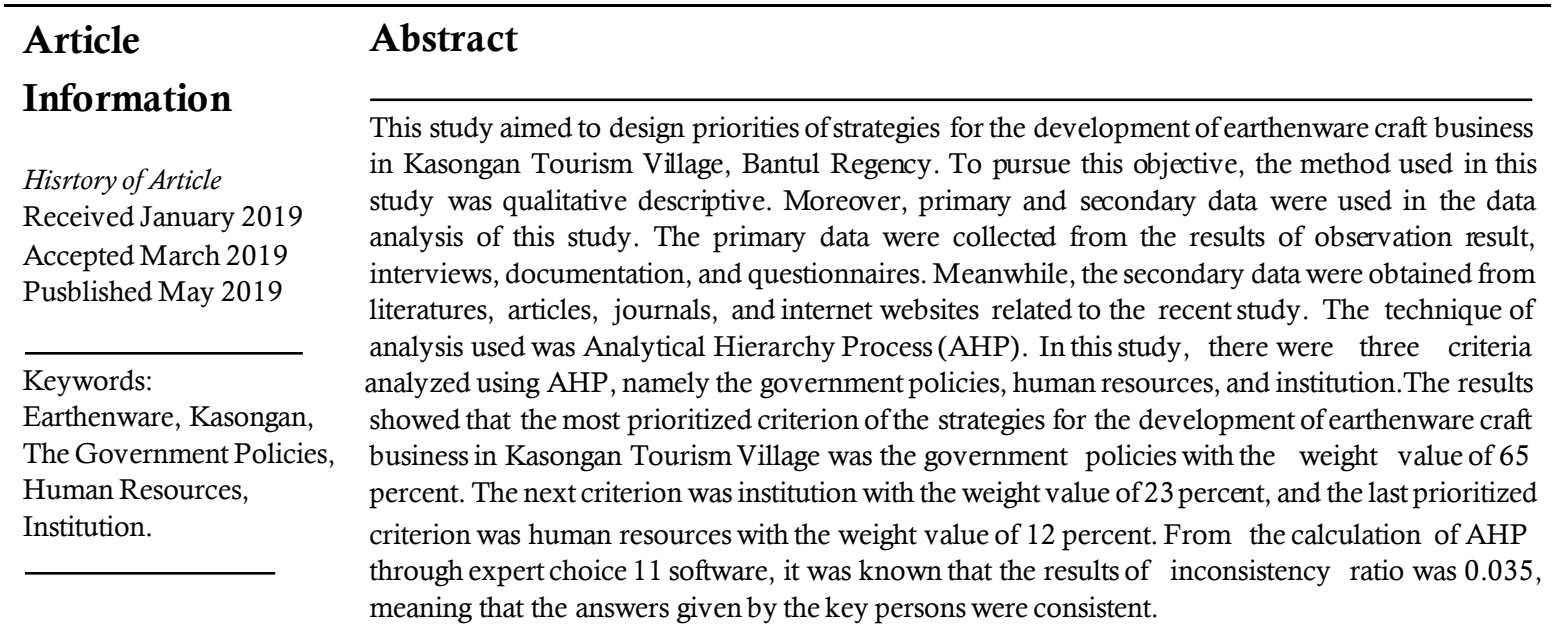

Address: Kota Baru Street, Sukaraja, Buay Madang, Ogan Komering

Ulu Timur Regency, South Sumatra 32361

E-mail: khafidismail@gmail.com 


\section{INTRODUCTION}

Micro Small and Medium Enterprises (MSME) hold an important role for the national economy. In 2015, MSME in Indonesia were able to contribute National Domestic Gross Products of $60.34 \%$. In addition, it also absorbed around $96.7 \%$ labor or 132.3 million of overall Indonesia population (Central Bureau of Statistic, 2016). It proves that the existence of MSME are labor intensive-based, utilize simple and easy to understand technologies, and able to be solutions for communities to work in line with their skills. They also could defend their position during the economic crisis in 1997-1998.

Along with the betterment on the development of economic level throughout Indonesia provinces, Yogyakarta is a province which cannot be underestimated in terms of craft products given its number of MSME. Bantul is one regency that is inevitably inseparable from Yogyakarta history as the city of struggle and Indonesia historical struggle in general. Bantul is a regency in DIY (Daerah Istimewa Yogyakarta) province that has various unique craft products such as in door and outdoor properties accessories, diverse wedding souvenirs, earthenware craft from clay, and many other products.

The Department of Cooperatives, SmallMedium Enterprises, Industry (KUMKP) of Bantul Regency recorded that the growth of MSME from 2011-2016 were 40\%. This growth was caused by the positive effects of the development of tourism attractions in Bantul Regency (The Department of KUMKP of Bantul, 2017). Also, Bantul Regency has so many ceramic craft centers known by both domestic and foreign people. Two of the famous ceramic craft centers in Bantul are located in Kasongan Village, and Pajangrejo Village. Kasongan ceramic craft is the most prominent one than other area. Kasongan Village community has been crafting earthenware functioning as households needs. However, the making of earthenware is not only limited to household properties, but also other stuffs having high selling value and the most wanted in markets. Today, earthenware products have various forms, covering unique small stuffs for wedding souvenirs, decorative ornament, pot, interiors (decorative lamps, sculpture, and furniture such as table, chairs). Even, the crafts cover various forms of surrounding environment such as artificial flower made of banana leaves, bamboomade household furniture, masks, and others (Pelupessy, 2017).

Kasongan's ceramic handicraft products are apparently not only sought after by tourists and buyers from various regions in Indonesia, but also by the world market, such as Europe, Japan, Australia, Canada and others since 1986. Uniquely, overseas buyers also like ceramic products with local designs. They also order ceramic products according to their tastes. Even among them bring examples of product designs from their home countries that have selling values, such as Buddha statues, Chinese army statues, various forms of jars, square pots, etc. (Fatimah, 2012). Even though Kasongan earthenware products are well-known everywhere, this does not guarantee its existence. In the last 10 years, in the period 2006-2016, the development of earthenware business in Kasongan Village did experience fluctuations, but tended to decline. This can be seen in figure 1 below: 


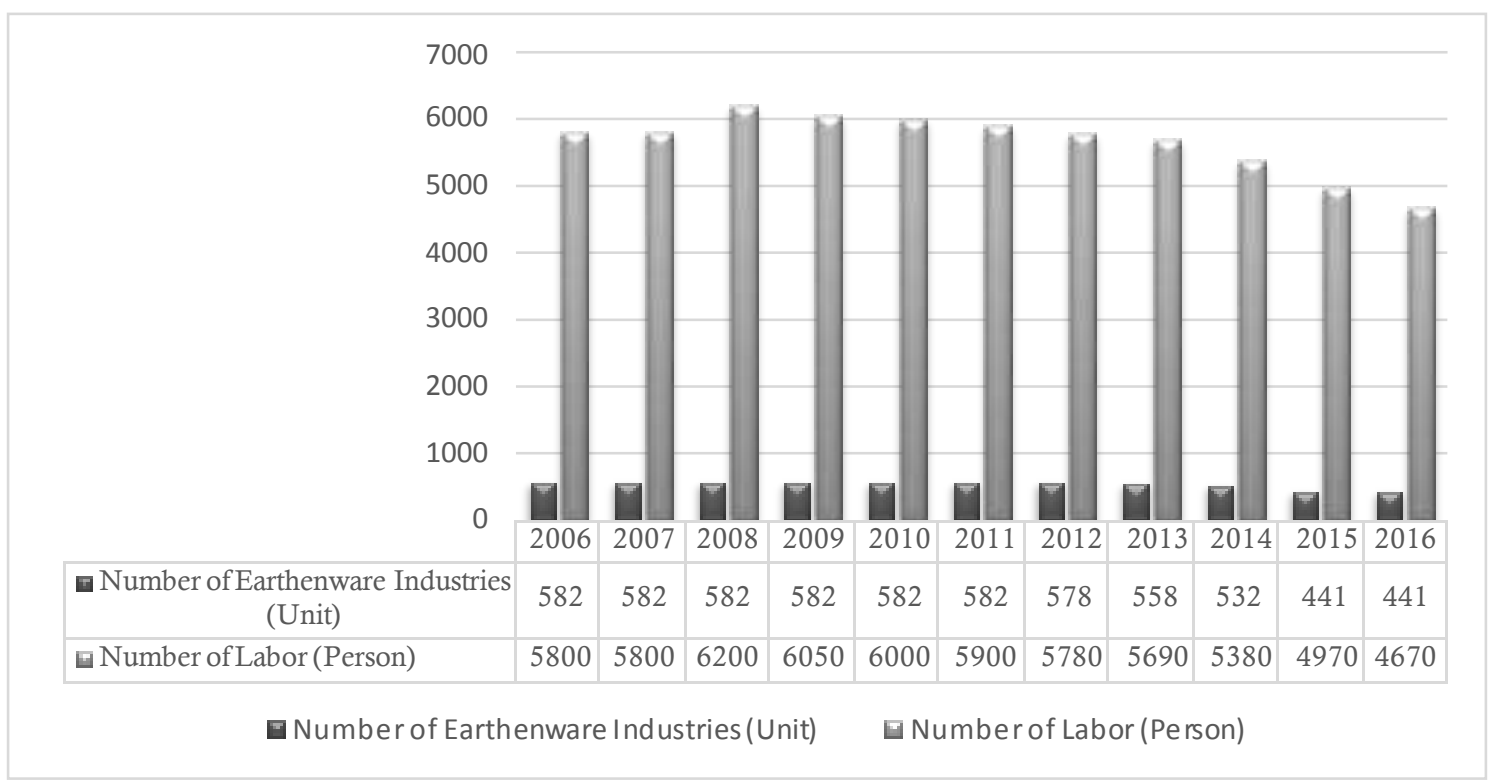

Figure 1. The Development of the Number of Business and Labor of Kasongan Earthenware Industry in the Period of 2006-2016.

Source: UPT Pengembangan Keramik Kasongan, 2017

Based on the above table 1 , it can be seen that the number of earthenware industry in Kasongan Village in the period of 2006-2016 experienced fluctuation. In 2006, there were 582 units of industry and could absorb 5,800 labors. However, in 2012, the number declined 578 units, and kept declining until 2006 of 441 units. Meanwhile, the total of labors also kept declining until 2006 of 4,670 people. The declination of the number of earthenware industries in Kasongan Village was followed by production volume. It can be seen in the following figure 2 :

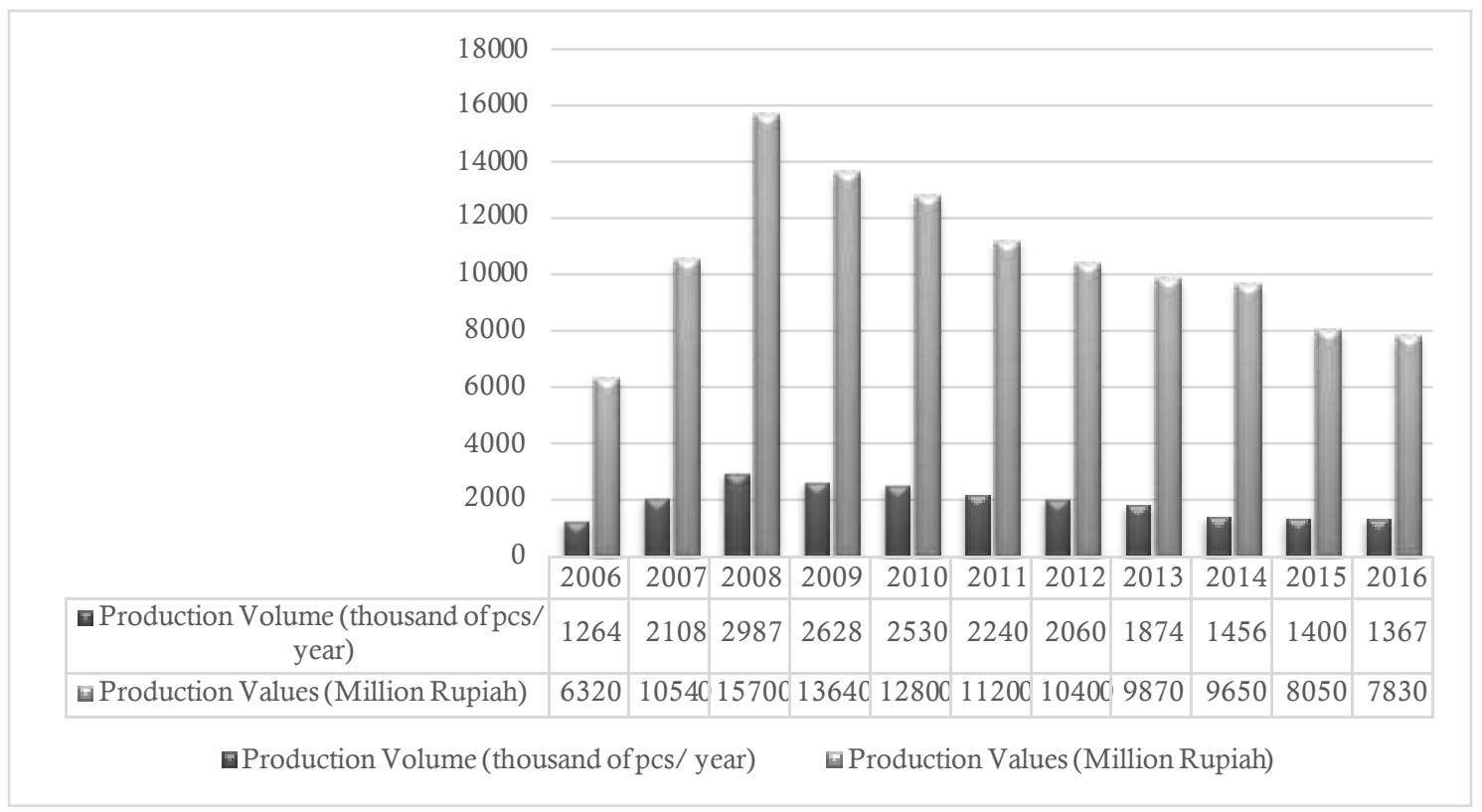

Figure 2. The Volume and Production Values of Kasongan Earthenware in the Period of 2006-2016 Source: UPT Pengembangan Keramik Kasongan, 2017 
Figure 2 shows that during 2006-2016 period, the production volume of Kasongan earthenware experienced a fluctuation and tended to decline in the past 7 years. In 2008, it was known that earthenware productions were $2,987 \mathrm{pcs} /$ year. However, in the next year of 2009 until 2016, the number kept declining amounted to $1,367 \mathrm{pcs} / \mathrm{year}$. The volume declination was followed by the production value, and resulted in the decrease in local community income.

The results of initial observation done to several earthenware craftsmen in Kasongan showed that there were several factors influencing the declination of earthenware production in Kasongan Village, namely the decrease in earthenware demand, expensive price of the raw materials, decrease in labors, limited capital, lack of facilities, weak institutions and partnerships, and increasingly fierce market competition. In Fatimah's (2012) study, it is mentioned that the majority of earthenware craftsmen in Kasongan need large capital because the prices of raw materials are increasingly expensive. The majority of the earthenware craft marketing method in Kasongan Village is by order, although some are displayed in the show room. The marketing model that relies on ordering is very closely related to demand factors. In recent years, the demand for earthenware has tended to decrease due to the large number of similar products that are more innovative so that the earthenware competitiveness decreases (Sofa, 2011). In the current era, earthenware craftsmen should take advantage of technological advancements to improve the marketing of their products in order to reach a wider market. One of the technologies that can be utilized is internet technology to conduct online promotion and marketing (Khotimah et al, 2013).

The clay used as earthenware raw materials is actually not difficult to obtain since it is availably plenty around Kasongan. Unfortunately, in the past recent years, the craftsmen should buy the war materials outside Kasongan with increasingly expensive price. Also, the limited capital ownership makes the craftsmen have trouble in doing optimum production (Hastuti, 2010). Additionally, the cheap price result in the low quality of raw materials. If the raw materials quality is low, it would significantly affect the quality of the products as well. (Miyoshi et. al, 2014). On the one hand, the earthenware industry in Kasongan generally has some labors in production process. However, most of the experts in this field come from outside Kasongan, namely Brebes Regency. As the time goes by, the experts start to decline because they choose to have another occ upation because they consider that the salary they earn is not enough to fulfill daily needs.

In Bank Indonesia study (2013), it is stated that the institution and business partnership of the earthenware craftsmen is very weak. It proves that the existence of Usaha Bersama Cooperative in Kasongan is not yet able to provide solutions for problems faced by the earthenw are craftsmen. For more, the majority of Kasongan craftsmen has not permanent partnership with companies or other industries so that they still have difficulties in marketing their products. The limited facilities such as traditional production equipment also contributes earthenware production not yet optimum. Actually, the production process is supposed to utilize modern technologies for the maximum results. Sumarno's study (2010) argues that the utilization of technology-based production equipment can increase production capacity and efficiency. Again, limited market information access by the craftsmen is very limited. This surely inhibits the marketing process since the craftsmen do not know the most wanted products by consumers, and what kind of business competition exists in the market (Pelupessu, 2017).

Of all existing problems faced by earthenware industry in Kasongan Village, the government through the Department of Cooperatives, Small-Medium Enterprises, Industry of Bantul Regency has tried to formulate policies in developing the earthen industry in Kasongan. There are many policies such as the formation of business incubator UPT for the industry, distribution of production equipment 
such as drying machine, and grinding mill, training and marketing accompaniment, supplying market access such as conducting exhibition, and capital. Unluckily, these policies are not fully able to develop the earthenware industry in Kasongan since the production keeps decreasing. The same also goes to accompaniment UPT which only has one caseworker so that the accompaniment is not yet optimum (The Department of KUMKP, 2018). This research seeks to provide novelty in the formulation of strategies to develop earthenware businesses that have not yet been applied to the pottery business in Kasongan, namely in the fields of innovation and institutional. Therefore, this study aimed to design priorities of strategies for the development of earthenware craft business in Kasongan Tourism Village, Bantul Regency.

\section{RESEARCH METHODS}

The design of this study was qualitative descriptive. It focused on the earthenware craft business in Kasong Tourism Village, Bantul Regency, Yogyakarta. The data used in this study covered primary and secondary data. The primary data were collected from the results of observation, interviews, documentations, and questionnaires. Meanwhile, the secondary data were gathered from literatures, articles, journals, and internet websites related to the current study. In addition, the secondary data were also obtained from the Development Planning Agency (Bappeda) of Bantul Regency, the Department of Cooperatives, Small-Medium Enterprises, Industry of Bantul Regency, and UPT Pengembangan Keramik Kasongan.

The samples were taken using purposive sampling technique covering six key persons considered knowing the problems being investigated as well as understanding what were expected in this study. The key persons came from Bantul Regency Bappeda, the Department of KUKMP of Bantul Regency, UPT Pengembangan Keramik Kasongan, and Setya Buwana Cooperative in Kasongan. Further, the researchers conducted oberservation, interviews, documentation and distributed questionnaires to collect the data.

The collected data were analyzed using Analytical Hierarchy Process (AHP). This method can help organizing a priority or goal of several options using some criteria. Alternatively, to decide the priority of the elements in a decision problem, there is a need to create pairwise comparison, namely each element is compared in pairs on a measured criterion. Through AHP, there would be some strategies to use as materials to develop strategies for the development of earthenw are craft business in Kasongan Tourism Village.

The variables used to design the criteria and the sub criteria as an alternative to decide policies priority in AHP were the government policies, human resources, and institution. In these three variables, there were various alternative programs for strategies for the development of earthenware craft business in Kasongan Tourism Village. In details, it had government policies criterion with five alternatives, human resources criterion with five alternatives, and institution criterion with four alternatives.

\section{RESULTS AND DISCUSSION}

This study employed AHP to organize priorities of the strategies for the development of earthenw are craft business in Kasongan Tourism Village. The analytical components used in this study covered several criteria and alternatives based on the results of literature reviews, previous studies, and interviews with the key persons who are experts in the field of earthenware craft business.

The key persons involved in this study were 6 people coming from from Bantul Regency Bappeda, the Department of KUKMP of Bantul Regency, (UPT) of Kasongan Ceramic Development, and a Cooperative underlying earthenware craft business in Kasongan. To obtain priorities, the first step was choosing several criteria and alternatives based on the results of observation and interviews with Bantul Regency Bappeda, and the Department of 
KUMKP. Based on the results of observation and interviews, the researchers obtained three criteria, namely the government policies, human resources, and institution. Of these criteria, the researchers selected several alternative to organize based on the results of AHP.

Based on calculations from the analytical hierarchy process for all the criteria of strategies for the development the earthenware craft business in Kasongan Tourism Village with the expert choice 11 program, the following results were obtained:

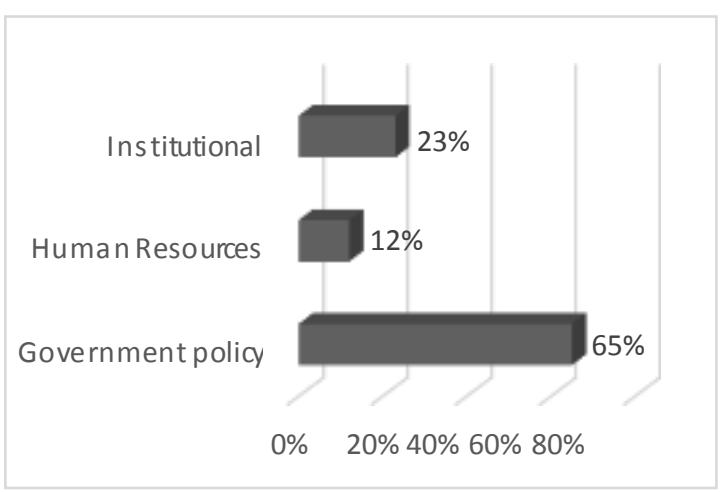

Figure 3. The AHP Output of All Criteria of Strategies for the Development the Earthenware Craft Business in Kasongan Tourism Village Source: Processed Primary Data, 2019

Based on figure 3 , it can be seen that the most prioritized criterion was the government policies with the weight value of 65 percent. The next criterion went to institution with the weight value of 23 percent, and the last priority was for the criteria of human resources with the weight vale of 12 percent. The results of AHP analysis on all criteria could be said consistent because the inconsistency value was only $0.0035<0.1$. This can be used as a basis for the development of the earthenware craft business in Kasongan Tourism Village.

Once the priority series was obtained, the next step was elaborating each criterion from the most prioritized to the less prioritized into several alternatives. Each criterion had some alternatives with different priority level. Also, each of the alternative surely had strengths and weakness which would complement and synergize to realize the development of earthenware craft business in Kasongan Tourism Village.

The criterion of the government policies had five alternatives, namely the provision of business capital requirements with alternative financing models and with soft interest, the provision of information facilities, promotion and market guarantees for earthenware craftsmen, the provision of assistance for vital production equipment, the provision of easy access to information and communication technology to earthenware craftsmen, and the provision of training and ease of business licensing and procurement of Intellectual Property Rights (IPR). Next, the criteria of human resources also had five alternatives, namely giving motivation to craftsmen to improve their skills and ability in producing earthenware, improving managerial capabilities and managing craftsmen's business, giving continuous workshop and training for craftsmen in creating innovation on earthenware craft, increasing the capacity of craftsmen to use renewable technology-based tools for production, and promotion and marketing training by utilizing information and communication technology.

Whereas, the institution criterion had four alternatives including improving the capacity and quality of a special institution for earthenware business, the establishment of an organization / community organization to establish cooperation between earthen ware craftsmen, the provision of training of cooperative management and earthenware craftsmen organizations, and improving business partnerships between earthenware craftsmen cooperatives with entrepreneurs / investor.

\section{The Analysis of Government Policy Criterion}

Based on the results of the Analytical Hierarchy Process (AHP) as seen in Figure 3, the government policy was the most prioritized criterion in the strategy for the development of earthenware craft business in Kasongan Tourism Village. The policy was an important element in supporting the development of the earthenware 
craft business in Kasongan. It could be in the form of programs that can overcome the problems faced by earthenware craftsmen in order to realize the development of the business.

Within this government policies criterion there were five alternatives analyzed using the Analytical Hierarchy Process (AHP). The results of the AHP calculation on the criteria for government policy were as follows:

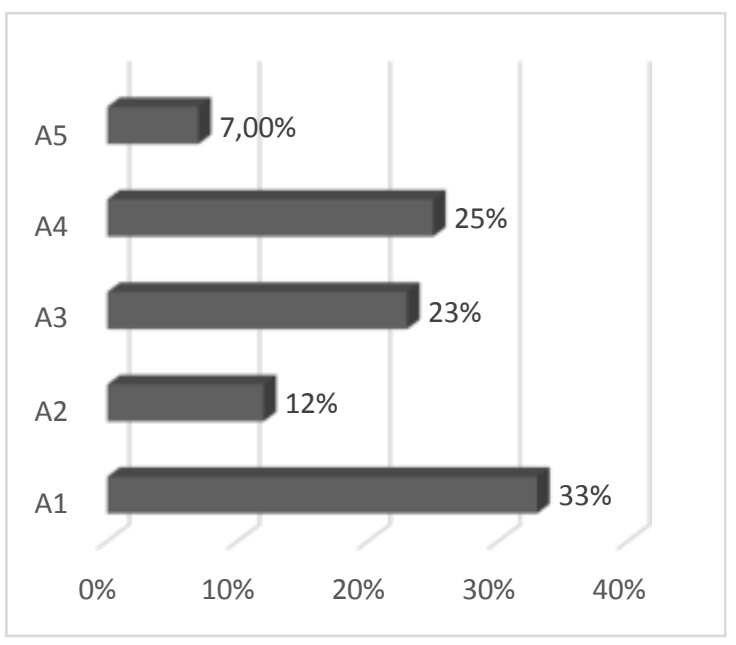

Figure 4. The AHP Output of the Government Policies Criterion

Source: Primary data processed, 2019

Information:

A1: The provision of business capital requirements with alternative financing models and with soft interests

A2: The provision of information, promotion and market guarantees for earthenware craftsmen

A3: The provision of assistance with vital production tools such as rotary machines, drying machine, combustion machine/ oven, and grinding mill

A4: The provision of easy access to information and communication technology to the craftsmen

A5: The provision of training and ease of business licensing and procurement of IPR

Figure 4 above showed that the most prioritized alternative in the government policies criterion was the provision of business capital requirements with alternative financing models and with soft interests with the weight value of 33 percent. Capital is one of the important elements in a business including earthenware craft business. The existence of capital will greatly affect the sustainability of a business. The greater the capital possessed by craftsmen, the greater the opportunity to produce earthenware and to fulfill customer orders will be (Hastuti, 2010). The capital in this criterion was in form of financial capital. Generally, the earthenware craftsmen in Kasongan run an earthenware business from production to marketing. Therefore, the capital they need is not small.

The problem they often face is the difficulty in obtaining capital loans so that their business is difficult to develop. Responding to this problem, the Bantul Regency government tried to provide alternative capital through loans with soft interest. This program synergizes with several banks and local financial institutions. However, it turned out that the conditions in the field showed that there were not a few pottery craftsmen having difficulties to obtain the program because of complicated processes and the conditions that were not fulfilling. Even though soft fees were applied, the existence of these loans was not accessible to all craftsmen because some of them could not fulfill requirements such as administrative requirements and business feasibility. This is certainly an obstacle to be sought for solution so that all craftsmen can obtain capital loans that do not burden their business.

The second priority alternative was the provision of easy access to information and communication technology to earthenware craftsmen with the weight value of 25 percent. In today's era, advances in technology and communication will greatly help earthenware craftsmen in obtaining access to information. So far, earthenware craftsmen have often been cheated by collectors due to lack of access to information, especially the selling price of earthenware information in the market. Every entrepreneur is required to always understand and know what is happening in the market and what the consumer wants, as well as various changes in his business environment so that he can compete with other entrepreneurs 
(Pelupessy, 2017). Therefore, the government has sought easy access to information and communication technology for earthenware craftsmen by providing several supporting facilities such as regular socialization through the UPT of Kasongan ceramics development and also the provision of facilities such as free wifi for craftsmen. Unfortunately, this program was also not optimal because the available facilities were still minimum and until now there are some wifi facilities that have been damaged and have not been repaired.

The alternatives of the third priority was the provision of vital production tools such as rotary machines, drying machines, oven, and grinding mill with the weight value of 23 percent. Production tools are important means of earthenware production. Unfortunately, the majority of the craftsmen in Kasongan are still using traditional tools. As a result, the products have not been optimum. The government of Bantul Regency through the Department of KUKMP has given several modern production tools such as rotary machine, drying machine, oven, and grinding mill. Through this provision, it was expected that the production would be more optimum, effective, and efficient. Besides contributing to production efficiency, these technology-based tools would increase the production capacity for the craftsmen as well as reducing exhaustion and injury (Hanafi, 2010).

The fourth priority alternative was the distribution of information, promotion and market guarantees for earthenware craftsmen. This priority weighted 12 percent. Lacks of facilities of promotion and marketing makes the craftsmen wait for customers' orders and sell their products directly to traditional markets. The marketting by demanding on customers' orders was neither stable nor as promising as in the past, especially for small erntrepreneurs given the sudden decrease in selling, and the appearance of other earthenware competitors from other area (Sofa, 2011). As a response for this, the government tried to provide promotion and marketting promotions in form of exhibition which could be joined by earthenware craftmen. Further, market guarantees were given to make tourists come to Kasongan Village as well as to sell earthenware. This program was aimed at giving a chance for the craftmen to look for broader markets. According to Nixiolek (2013) the broad market are would contribute positive affects to a busineses, particularly earthenware business. The broader the market area for earthenware craft, the bigger chances for the craftment to develop their business.

The fifth priority was the provision of training and ease of business licensing and procurement of IPR. A business can be said to be legal if it has a business license. In addition to business legality, the existence of intellectual property rights (IPR) is also needed by business people to protect the copyright of thire products. However, most of the Kasongan pottery business actors still had a difficulty managing business licenses and IPR. This certainly had an effect on the difficulty of obtaining credit access and ease of marketing, especially the scale of exports, considering that credit requirements also require administration in the form of a business license. The local government shought to provide training and facilities for pottery craftsmen to do business licensing and procure intellectual property rights so that the business es they run can be more developed.

\section{The Analysis of Institution Criterion}

The second prioritized criterion in the strategies for the development of earthenware craft business in Kasongan Tourism Village was institution criterion. One of the inseparable element in developing earthenware business is institution. The institution element will significantly influence on the development of the business. In this criterion, there were four alternatives analyzed using AHP. In addition, the results of AHP calculation on institution criterion were as follows: 


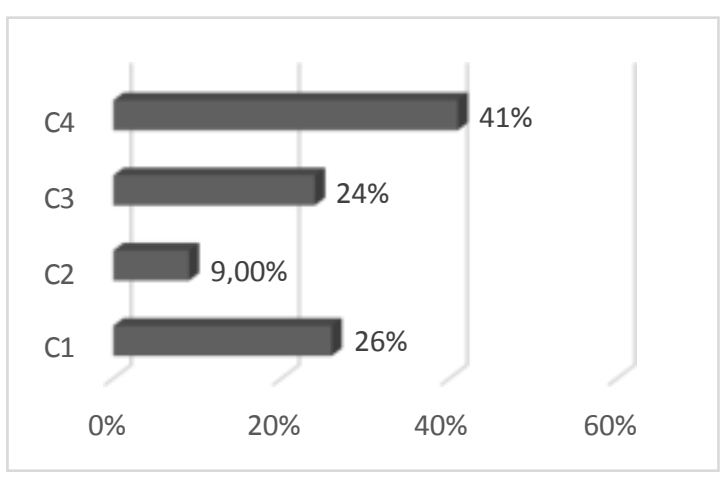

Figure 5. The AHP output of Institution Criterion

Source: Processed Primary Data, 2019

Information:

$\mathrm{C} 1$ : improving the capacity and quality of a special assistance agency for earthenware business,

C2: the establishment of an organization / community organization to establish cooperation between earthenware craftsmen

C3: training of cooperative management and earthenware craftsmen organizations

C4: improving business partnerships between earthenware craftsmen cooperatives with entrepreneurs / investor.

Based on Figure 5, it could be explained that the most prioritized alternative in institution criterion was an improvement in business partnerships between earthenware craftsmen cooperatives with entrepreneurs / investors with the weight value of 41 percent. In Kasongan Tourism Village there is a pottery craftsman cooperative named Koperasi Setya Buwana. The existence of the cooperative is very helpful for craftsmen both in terms of exchanging information and in capital loans. However, the financial capacity of this cooperative is not large, so it requires partnerships with several other institutions or companies. There are several State Owned Enterprises (BUMN) that have already partnered with earthenware craftsmen cooperatives in Kasongan, namely PT Pusri, PLN, Pos Indonesia, Perum Peruri, Telkom, Indosat, Angkasa Pura II and others. The existence of this partnership is expected to be able to help earthenware craftsmen to develop their business.

The second priority alternative was to improve the capacity and quality of a special assistance agency for earthenware business with the weight value of 26 percent. In Kasongan Tourism Village there is an agency named UPT Pengembangan Keramik Kasongan. The UPT was formed by the Bantul Regency KUKMP Service whose task is to provide assistance to the earthenware craftsmen in Kasongan. However, the obstacle faced by this UPT was the lack of assistant member, namely only one person and he must accompany all earthenware craftsmen in Kasongan. Supposed one companion accompanies five craftsmen. Therefore, it is necessary to add the number of companions in this UPT for the maximum results.

The third priority alternative was training of cooperatives management and earthenware craftsmen organizations with the weight value of 24 percent. The existence of cooperatives as an institution that accommodates earthenware craftsmen is clearly very useful. However, the existence of cooperatives was inhibited by cooperative management that has not been maximized. The majority of Koperasi Setya Buwana administrators are high school graduates, so their managerial abilities are still minimum. Therefore, the KUKMP Service provides assistance and training for the management of these cooperatives in order to improve their managerial capabilities.

The fourth priority alternative was the establishment of an organization / community organization to establish cooperation between earthenware craftsmen with a weight value of 9 percent. So far, earthenware craftsmen in Kasongan had no group or associations. This was because there were still many craftsmen who were individualistic in nature, so it was difficult to cooperate with other craftsmen. This problem certainly led to unfair business competition which would harm the craftsmen themselves. Therefore, the local government was planning to form a community forum for the craftsmen to establish mutually beneficial cooperation. This effort was supported by the clustering of the 
earthenware industry in Kasongan so that each craftsman can more easily cooperate.

\section{The Analysis of Human Resources}

The last prioritized criterion was human resources. This was an inevitable important aspect as an effort to develop earthmenware craft business in Kasongan. These resources are directly interacted with earthenware business starting from production process until marketing process. The higher quality of human reources, the more developed the business would be. On the other hand, obstacles faced in improving the quality of human resources was the low educational background labor. This certainly affected their skills and ompetences. Even though they have been expert in the making of earthenware, but they have not been able to think forward to keep up with the times both in terms of aspects of production innovation and marketing innovation.

In addition, the majority of earthenware craftsmen in Kasongan are from Brebes because Brebes people skills in making earthenware are more qualified compared to local residents. But at this time, many craftsmen who came from the brebes returned to their regions because the wages they received were felt lacking. As a result, craftsmen who have qualified skills diminish. Therefore, a number of development programs for earthenware craftsmen were needed. In the HR (human resources) criterion, there were five alternatives analyzed using the Analytical Hierarchy Process (AHP). The results of the AHP calculation on the criteria of human resources were as follows:

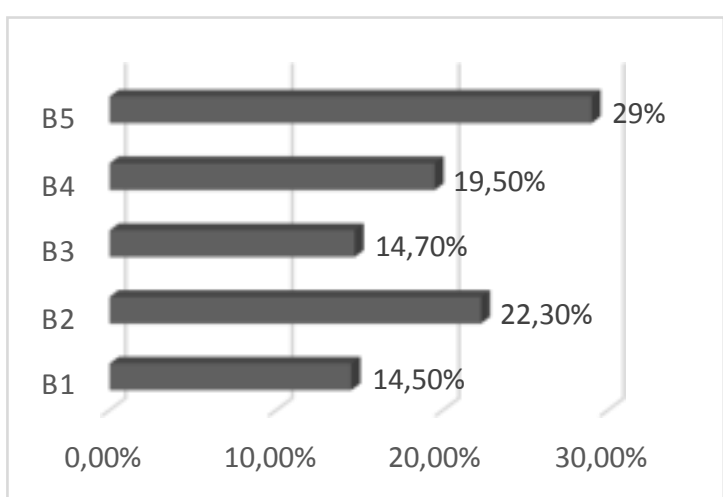

Figure 6. The AHP Output of Human Resources Criterion
Information:

B1: The provision of motivation to the craftsmen in order to improve their skills and ability in producing earthenware

B2: improving managerial capacity and business management skills

B3: the implementation of continuous guidance and training to the craftsmen to create innovation in earthenware craft.

B4: improving the craftsmen capacity in the utilization of renewable technology-based production tools

B5: Promotion and marketing training by employing technology, information and communication

Figure 6 shows that the most prioritized alternative on the criteria of human resources was promotion and marketing training by employing technology, information and communication with the weight value of 29 percent. Promotion and marketing was one of the important elements for a business including earthenware craft business. So far, the earthenware craftsmen in Kasongan marketed products only in traditional markets, displayed in showrooms and based on orders from consumers. In addition there were also some who went through several exhibitions and also exports, but it was only a few given that the costs required to attend an exhibition were not small and the process of exporting was also not easy. Current technology advances and the rise of online marketing are supposed to be utilized by the earthenware craftsmen to sell their products.

The local government through the KUKMP service has conducted online promotion and marketing training by utilizing available internet facilities. The use of internet technology to improve the competitive advantage of earthenw are MSME is an interesting solution. Besides being used for promotion, the sale of goods can be done through the internet (Khotimah et al, 2013). However, the training was only conducted several times and not all craftsmen asked to follow it so the results were not optimal. 
The second priority alternative was to increase managerial capacity and business management skills with the weight value of 22.3 percent. The majority of the educational backgrounds of the earthenware craftsmen were elementary and junior high school graduates, so their ability to manage and organize their business has not been maximized. Craftsmen did not necessarily carry out financial bookkeeping so there is no certainty about the development of the business they are running. The local government, through the UPT Kasongan Ceramic Development Unit provided assistance to the craftsmen to be able to manage their businesses well so that their businesses could develop.

The third priority alternative was to improve the craftsmen capacity in the utilization of renewable technology-based production tools with the weight value of 19.5 percent. Technology advances provide many benefits in the business sector and industry, especially the earthenware craft business. The process of making earthenware has many steps, so it requires production equipment that is not small and varied. The Bantul Regency Government has provided assistance in the form of modern earthenware production equipment with the use of technologies such as rotary machines, drying machines, oven, and grinding mill. The assistance aimed to increase the capacity and efficiency of existing earthenware production in Kasongan. However, the problem was that not all craftsmen were able to operate these modern production tools. Not even a few of them continue to use the traditional production tools they have. According to a study by Ueda et al. (2017) the majority of earthenware craftsmen, especially in Southeast Asia, tend to survive using traditional production equipment because they are used to and are a hereditary cultural heritage to do. Therefore, it is necessary to provide assistance and training to the craftsmen so that they can properly and optimally help support the production equipment.

The fourth priority alternative was the implementation of continuous guidance and training to the craftsmen to create innovation in earthenware craft with the weight value of 14.7 percent. Innovation is an important element in earthenware crafts. The more innovative earthenware produced, the more the product will be enjoyed by consumers. An innovative product will have a surplus value compared to competitors' products or substitute products, and these innovative products will create their own market segments and spin off against products that are old and inefficient (Sumarno, 2010). The skill of the earthenware craftsmen in Kasongan is indeed undoubted. Unfortunately, in terms of product innovation, especially innovation in accordance with what was in demand in the market, not all craftsmen were able to create these innovations. This was because their products tended to be monotonous. Even today there are many earthenware products with renewable innovation coming from other regions that compete with Kasongan. As a result, the effort of providing guidance and training has been continuously given by the Department of KUMKP of Bantul Regency. According to Henden et al. (2012) innov ations in earthenware craft design need to be done because consumer desires and interests can change at any time according to the era.

The last priority alternative on the criteria of human resources was the provision of motivation to the craftsmen in order to improve their skills and ability in producing earthenware with the weight value of 14.5 percent. Skilled and professional human resources will produce high quality products which have great interest and influence the handicraft business they run (Hastuti, 2010). So far, the capabilities and skills of the earthenware craftsmen in Kasongan have surely been qualified. However, not a few of them were reluctant to improve their skills because there was no encouragement and motivation. If in entrepreneurship someone does not have a strong motivation for entrepreneurship, does not take action in the form of innovation, it is unlikely that a business will experience growth (Yunal \& Indriyani, 2013). The craftsmen assumed that the most important thing was the production of earthenware could continue to run and they 
could earn some profit. This assumption would certainly backfire for their business given that in the current era there are various competitors for earthenware products. In addition, not a few of them were traumatized by the 2006 earthquake. When the earthquake occurred, many of their production equipment was destroyed and the finished pottery products were also destroyed, so they happened to stop producing earthenware for about three months (Hastuti, 2010). This incident made the earthenware craftsmen traumatized and finally they were less motivated to produce earthenware in large quantities. Further, motivation continues to be given by the local government by providing assistance and guidance as well as awareness for earthenware craftsmen to continuously improve their skills so that their businesses continue to grow.

\section{The Alternative Sequen ce of Strategies for the Development of Earth enware Craft B usiness in Kasongan Tourism Village}

Based on calculations from the analytical hierarchy process for the overall alternative strategy for the development of earthenware craft business in Kasongan Tourism Village with the expert choice 11 program the following results were obtained:

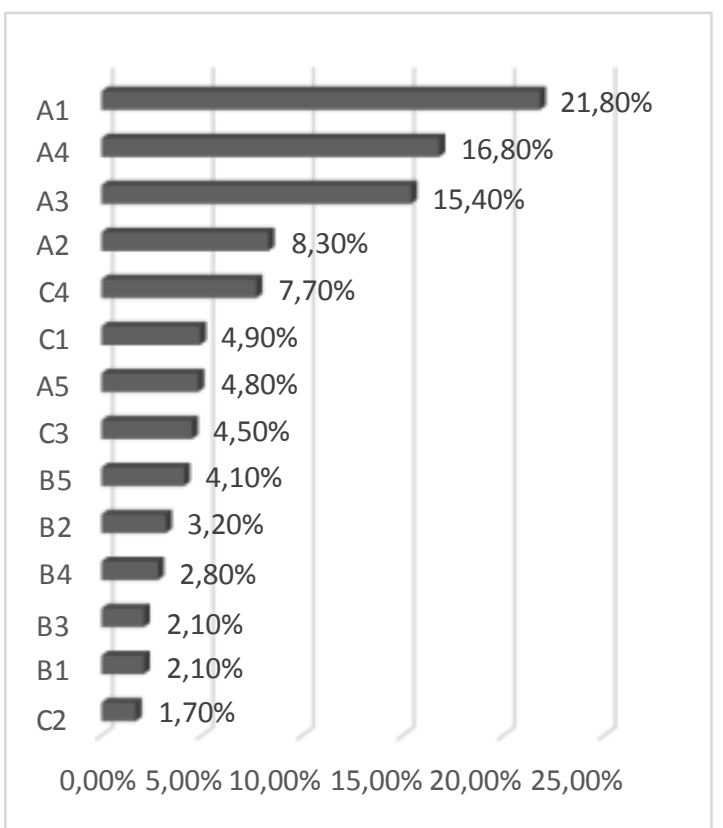

Figure 7. The AHP output of the Overall Alternatives
Source: Processed Primary Data, 2019

Information:

A1: The provision of business capital requirements with alternative financing models and with soft interests

A4: The provision of easy access to information and communication technology to the craftsmen

A3: The provision of assistance with vital production tools such as rotary machines, drying machine, combustion machine / oven, and grinding mill

A2: The provision of information, promotion and market guarantees for earthenware craftsmen

C4: improving business partnerships between earthenware craftsmen cooperatives with entrepreneurs / investor.

$\mathrm{C1}$ : improving the capacity and quality of a special assistance agency for earthenware business,

A5: The provision of training and ease of business licensing and procurement of IPR

C3: The provision of training of cooperative management and earthenware craftsmen organizations

B5: Promotion and marketing training by employing technology, information and communication

B2: improving managerial capacity and business management skills

B4: improving the craftsmen capacity in the utilization of renewable technology-based production tools

B1: The provision of motivation to the craftsmen in order to improve their skills and ability in producing earthenware

B3: the implementation of continuous guidance and training to the craftsmen to create innovation in earthenware craft.

C2: the establishment of an organization / community organization to establish cooperation between earthenware craftsmen

Based on Figure 7, the most prioritized alternative in the strategy for the development earthenware craft business in Kasongan Tourism 
Village was the provision of business capital requirements with alternative financing models and with soft interests with the weight value of 21.8 percent. Then the second priority alternative was the provision of easy access to information and communication technology to the craftsmen with the weight value of 16.8 percent. The third alternative priority was the provision of assistance with vital production tools such as rotary machines, drying machine, combustion machine / oven, and grinding mill and so on until the last or fourteenth priority in the strategy for the development of earthenware craft business in Kasongan Tourism Village, namely the establishment of an organization / community organization to establish cooperation between earthenware craftsmen with the weight value of 1.7 percent.

The earthenware craft business in Kasongan Tourism Village has been existing for a long time, but until now it has not been able to progress due to the many problems faced by craftsmen, one of which was the difficulty in obtaining capital loans / loans. This has actually been attempted by the existence of the Setya Buwana cooperative which consists of earthenware craftsmen as the members. The existence of this cooperative is very helpful for earthenware craftsmen especially in capital assistance. However, the capital that can be lent by the cooperative is a maximum of only 5 million for each craftsman. In addition to cooperatives, there is also access to capital from banks that can provide loans with a larger nominal of up to 50 million. The banks which can provide this loan are such as Bank Mandiri, Bank DIY, and BPR. However, not all the craftsmen can obtain the loan, especially the small-scale earthenware entrepreneurs so that the managerial capabilities of these entrepreneurs are still minimal.

In addition to capital, information access is something that cannot be ignored from earthenware craftsmen. Information becomes an important thing for earthenware entrepreneurs, especially regarding competitors' products information and price information on the market. Information plays a role in influencing the formation of changes in a person's attitude towards an object / product. The higher the intensity of information obtained by someone will stable his attitude towards the choice, and will eliminate uncertainty (Sumarno, 2010). The lack of information access for earthenware craftsmen has made it difficult for their businesses to grow and develop. They must know the information about the products consumers are interested in in the market so that the products they produce sell well. In addition, the information on the price of earthenware in the market must also be known by craftsmen. Less market information causes the price of earthenware they sell to be uncertain because they must be tricked by middlemen. Responding to this, the local government has provided easy access to information for craftsmen through the UPT Pengembangan Keramik Kasongan by providing regular assistance.

In today's era, technology advancement is an opportunity that can be used to advance a business, including the earthenware craftsmen's business. One of the technologies is the technology of production equipment. Technology-based production equipment will provide benefits to craftsmen, especially in creating efficiency and production innovation (Sumarno, 2010). So far, the earthenware craftsmen in Kasongan generally still use traditional production equipment so that the production process they have carried out has not been maximized and efficient. The Bantul Regency Government through the Department of KUKMP has provided assistance by distributing modern production equipment to support the production process of earthenware for craftsmen in Kasongan. This assistance can help the craftsmen to improve production efficiency and create more innovative earthenware products according to consumer desires. In Bland's research, et.al (2017), it is stated that the use of technology in earthenware production, especially in the process of burning, will create better and stronger quality of earthenware because the combustion process with the oven has even heat. In Idrissi et.al's study (2018) it is stated that the quality of good 
earthenware will affect its price. The higher the quality of a product, the higher the price will be. Another important strategy for the development of earthenware business is the establishment of an organization / community organization to establish cooperation between earthenware craftsmen. Even though this alternative took place in the last priority, but the establishment should not be excluded. The existence of this organization will provide a special place for craftsmen, especially in terms of cooperation and coordination (Hastuti, 2010). The cooperation is in term of earthenware marketing. The large-scale earthenware craftsmen are generally able to sell their products to the export market. However, to meet the export market demand, they certainly must have a large production capacity. Therefore, these large-scale craftsmen can collaborate with smallscale craftsmen in fulfilling the demand for earthenware in the export market. Thus, profits will be made between the fellow craftsmen in Kasongan.

\section{CONCLUSION}

Based on the description of the results and discussion, it can be concluded that the most prioritized criteria in the strategy of developing a pottery craft business in Kasongan Tourism Village is the government policies criterion with the weight value of 65 percent. Then the second priority is institution criterion with the weight value of 23 percent and the third or final priority is the criterion of human resources with the weight value of 12 percent. The results of the AHP analysis of the overall criteria can be said to be consistent because the inconsistency value was only $0.0035<0.1$. These results can be used as a reference for the development of the earthenware craft business in Kasongan Tourism Village.

Furthermore, the most prioritized alternative sequence in the strategies for the development of earthenware craft business is the provision of business capital requirements with alternative financing models and with soft interests with the weight value of 21.8 percent. Second, the provision of easy access to information and communication technology to the craftsmen with the weigh value of 16.8 percent. Third, the provision of assistance with vital production tools such as rotary machines, drying machine, combustion machine / oven, and grinding mill until the last priority, namely the establishment of an organization / community organization to establish cooperation between earthenware craftsmen with the weight value of 1.7 percent.

\section{REFERENCES}

Badan Pusat Statistik. (2016). Profile of MSMEs in Indonesia. Website: https://www.bps.go.id/. (Diakses pada 20 April 2019).

Bland, C. A., Roberts, A. L., Popelka-Filcoff, R. S., \& Santoro, C. M. (2017). Early vitrification stages identified in prehistoric earthenware ceramics from northern Chile via SEM. Journal of Archaeological Science: Reports, 16, 309-315. doi:10.1016/j.jasrep.2017.09.011

Dinas Koperasi dan Usaha Kecil Menengah Kabupaten Bantul. (2017). Profile of MSME Development in Bantul Regency. Website: https://diskukmp.bantulkab.go.id/. (Diakses pada 20 April 2019).

E1 Boudour E1 Idrissi, H., Daoudi, L., ElOuahabi, M., Collin, F., \& Fagel, N. (2018). The influence of clay composition and lithology on the industrial potential of earthenware. Construction and Building Materials, $\quad 172, \quad 650-659$. doi:10.1016/j.conbuildmat.2018.04.019

Fatimah, Yuni Faridatul. (2012). Industrial Study of Kasongan Pottery Craft in Bangunjiwo Village, Kasihan District, Bantul Regency. Jurnal Seni dan Kewirausahaan. Vol. 7 (1).

Hanafi, Muhammad. (2010). Redesigning Work Facilities for Pottery Makers by considering Ergonomic Aspects. Essay. Universitas Sebelas Maret.

Hastuti, Indra. (2010). Industrial Development of Pottery Crafts, Factors Affecting and Its Empowerment Strategy in Melikan Villages in Wedi District, Klaten Regency. Jurnal Ekonomi dan Bisnis. Vol. 3 (1).

Henden, E., Cataloglu, R., \& Aksuner, N. (2011). Determination of arsenic leaching from glazed and non-glazed Turkish traditional earthenware. Science of The Total Environment, 409(15), 2993-2996. doi:10.1016/j.scitotenv.2011.04.027

Khotimah, Tutik dan Rina Fiati. (2013). Increased Competitive Advantage in Pottery Centers 
Through E-Business Models. Jurnal Simetris. Vol. 3 (1).

Miyoshi, Y., Nagano, M., Ishigo, S., Ito, Y., Hashiguchi, K., Hishida, N., ... Hamase, K. (2014). Chiral amino acid analysis of Japanese traditional Kurozu and the developmental changes during earthenware jar fermentation processes. Journal of Chromatography B, 966, 187-192. doi:10.1016/j.jchromb.2014.01.034

Niziolek, L. C. (2013). Earthenware production and distribution in the prehispanic Philippine polity of Tanjay: results from laser ablation-inductively coupled plasma-mass spectrometry (LA-ICP-MS). Journal of Archaeological Science, 40(6), 28242839. doi:10.1016/j.jas.2013.02.020

Pelupessy, Merry Margareth. 2017. Marketing Performance Analysis in Pottery Processing Industry in Takalar District, South Sulawesi Province. Jurnal Manis. Vol 1 (1).

Sofa, Innes Maeya. (2011). Economic Empowerment of Pottery Craftsmen: Case Study of Kasongan Pottery Craftsmen in Bangunjiwo Village, Bantul Regency. Jurnal Ekonomika. Vol 3 (1).
Sumarno, Muhammad. (2010). Level of Adoption of Technology Innovation for Entrepreneurs in the Small Industrial Center of Kasongan Earthenware Crafts in Bantul Regency. Jurnal Manajemen dan Kewirausahaan. Vol. 12 (1).

Ueda, K., Miksic, J. N., Wibisono, S. C., Harkantiningsih, N., Goh, G. Y., Edwards McKinnon, E., \& Shah, A. M. Z. (2017). Trade and consumption of fine paste ware in Southeast Asia: Petrographic and portable X-ray fluorescence analyses of ninth- to fourteen th-century earthenware. Archaeological Research in Asia, 11, 58-68. doi:10.1016/j.ara.2017.05.004

UPT Pengembangan Keramik Kasongan. (2018). Business Development of Pottery in Kasongan Tourism Village. Report Recap.

Yunal, Vivin Oblivia and Ratih Indriyani. (2013). Analysis of the Effect of Entrepreneurial Motivation and Product Innovation on the Growth of the Pottery Craft Business in West Lombok. Jurnal Agora. Vol. 1 (1). 